\title{
Expansionary or restrictive policies in the Eurozone? Dominating trends in the first two decades
}

\author{
JOANNA STAWSKA $^{1 *}$ (1) and PAULO JORGE REIS MOURAO ${ }^{2}$ (C) \\ ${ }^{1}$ Department of Finance, University of Lodz, 39 Rewolucji 1905, 90-214 Lodz, Poland \\ ${ }^{2}$ Department of Economics \& NIPE, University of Minho, Braga, Portugal
}

Received: November 3,2019 • Revised manuscript received: February 5, 2020 • Accepted: February 28, 2020

(๔ 2021 Akadémiai Kiadó, Budapest

\begin{abstract}
Our aim is to identify periods of restrictive versus expansionary economic policy in the euro area in the last two decades. We firstly conducted the study for identifying the dominant trend in fiscal policies and then in monetary policies. We studied several fiscal outputs, focusing on the cyclical adjusted primary balance. We also analysed the European long-term and short-term interest rates. The study was conducted for several windows, namely for 3-, 4- and 5-year periods. Additional procedures were conducted for robustness checks, namely the study of structural breaks in the analysed time series as well as a study of them recurring to Markov-Switching Regimes models. For most of the analysed periods and subperiods of the series, we concluded for the presence of expansionary policies either in the fiscal or in monetary European domains. Finally, the results and the analysis of dependencies in the euro area economy favour the evidence that economic authorities in the euro area have sought to coordinate monetary and fiscal policy to stabilise the economy.
\end{abstract}

\section{KEYWORDS}

expansiveness, fiscal policy, monetary policy, policy mix, restrictiveness

JEL CLASSIFICATION INDICES

E02, E4, E52, E62

*Corresponding author. E-mail: joanna.stawska@uni.lodz.pl 


\section{INTRODUCTION}

In the EU, the freedom of national authorities at conducting fiscal and monetary policies is limited by the Maastricht Treaty and Stability and Growth Pact. The first aim of the article is to identify periods of restrictive versus expansionary economic policies in the Eurozone (EZ) in the context of policy-mix coordination, the nature of these policies and their mutual impact on the economy. Secondly, we want to contribute to the clarification of the dominant force of the EZ, namely we want to check whether the restrictive or expansionary policies have been the most evidenced policies in the Euro project.

The structure of the paper is as follows. Section 2 presents the review of studies focused on the debate about the coordination of policy mix and the directions of monetary and fiscal policies in the European economies. In Section 3 the expansiveness and restrictiveness of monetary and fiscal policies in the EZ were tested through the descriptive methodology purposed by authors like Czyżewski - Kułyk (2010) and through a robustness analysis of structural breaks and Markov-switching regimes in the observed series. The last section presents the conclusions.

\section{LITERATURE REVIEW}

As we have a diversity of instruments for monetary and fiscal policies, we also have a diversity of 'target' dimensions in monetary and fiscal policies (Bennett - Loayza 2000). In monetary policies, dimensions like the various subsets of money supply (M1, M2, M3, ..) or the different interest rates (usually divided in short-term or long-term rates) tend to be identified as monetary outcomes. In fiscal policies, the primary balance (i.e., the difference between public revenues and public expenses without the charge of interests' expenses from public indebtedness) or the relationship between the primary balance to other economic aggregates, like its percentage in a country's GDP, has been found as the most commonly discussed outcomes (Samuelson 1968). According to that approach a notion of coordination was formulated by Nordhaus (1994), who claimed that a coordinated macroeconomic policy is observed when central banks' interest rates adjust appropriately so that effects of fiscal policy can be neutralised.

Authors of the Keynesian school tended to discuss the impact of fiscal and monetary policy on the economy using an IS-LM model, i.e., a synthetic representation of the "investmentsaving" (IS) and "liquidity preference-money supply" (LM) curves, graphed on a two axes-interest rate (ordinates) and real output in goods and services market plus money market (abscissa). The expansiveness or restrictiveness of both policies were expressed in this model through the appropriate shift of the curves. In turn, preference for the expansive fiscal policy was related to the departure from the classical theory of public finance - identified with the principle of balanced budget. Keynesians argued that the expansive fiscal policy and connected budget deficit are allowed to counteract the short-term declines in economic activity and additional expenses through multiplier effects which contributed to employment and product growth (Fand 1969; Snowdon et al. 1996; Midthjell 2011).

In the Euro Area (EA) the debate about policy-mix (Flanagan et al. 2011) has been based on a common monetary policy for all members of the Monetary and Economic Union (EMU) and different/autonomous national fiscal policies (Jacquet - Pisani-Ferry 2001; Buti 2003; von 
Hagen - Mundschenk 2003; von Hagen 2004; Canzoneri et al. 2006; Ferré 2008; Pisani-Ferry 2012; Cabral - Garcia 2015). Here, we should refer to the results of Badarau - Levieuge (2011), who discussed whether the policy-mix was suitable to the EMU in a context of financial heterogeneity. Using dynamic, stochastic general equilibrium model (DSGE), they detailed relevant implications for the policy-mix coordination. They have ascertained that the centralised monetary policy was more advantageous than the national monetary policies. They also have found that the national budget policies can mitigate cyclical divergences. Nevertheless, the analysis of various cases of policy-mix shows certain advantage of the common budget and it allows better price stability in the EMU.

In the case when the economic authorities are unwilling to cooperate with each other, Nash equilibria generates higher levels of inflation and lower levels of production compared with the best solution achievable under the given circumstances (but still not optimal, because of the disturbances caused by the fiscal policy). The reason for this is a mismatch between the central bank seeking to reduce production and inflation below the levels set by the government and the government pursuing a fiscal policy increasing inflation and production above the levels defined by the central bank. This is a case of an inflationary fiscal policy partly offset by the monetary policy (Dixit - Lambertini 2003).

Since the integrated discussion provided by Haberler (1976), the coordinated monetary and fiscal policies are still an open debate. Analysis of the models based on game theory indicates that the coordination of these policies would be beneficial for the economy (Clarida et al. 2000; Badarau - Levieuge 2011; Cui 2016). The harmonisation of these two policies limits the sources of conflict, leads to the minimisation of costs of maintaining price stability and contributes to the greater stability of the financial system (Sargent - Wallace 1981; Blake - Weale 1998; Demertzis et al. 2002; Dixit - Lambertini 2003; Chadha - Nolan 2007). The use of these models allows to observe the problems also arising from the conflict of monetary and fiscal authorities (Payer 1974). A lack of such coordination was criticised, e.g., by Nordhaus (1994) and Saulo et al. (2013).

The various analysis show that the combinations of economic policies are depending on the total level of aggregate demand that can be influenced by the fiscal policy, the monetary policy and their combination. Studies from Kuttner (2002) or from Stiglitz (2007) attribute a major role for the central bank in maintaining macroeconomic stability in the country to the insufficient flexibility of a fiscal policy as a stabilisation tool. In models like Kuttner (2002), a fiscal policy is assumed to produce a demand shock that should be offset by the monetary authorities.

Relevant conclusions in the context of our research were also presented by WoronieckaLeciejewicz (2015) indicating that under the influence of changes in the central bank and government priorities, the optimal fiscal and monetary responses change and, as a result, the Nash equilibrium shifts (equilibrium as a choice of policy mix). When the fiscal authorities plan a higher growth rate, the optimal budgetary response becomes more expansive. Additionally, a change in the priorities of the monetary authorities, like permitting a higher level of inflation (by lower interest rates), causes a shift in the optimum monetary strategies resulting in a more expansive monetary policy.

In the debate of expansiveness or restrictiveness of fiscal, monetary or economic policy, Czyżewski - Kułyk (2010) examined whether the impact of a specific policy was significant into the macroeconomic situation. The analysis comprised determination of a dominant option of economic policy understood in such a way that within the business cycles a level of interest rate or budget deficit was changing more extensively. In order to set a dominant option of economic 
policy they used a pendulum model, in which economic policy was perceived as a synthetic indicator of the effects of fiscal and monetary policy. Monetary policy was determined as a standardized indicator of a level of long-term interest rate, whereas fiscal policy as a standardized indicator of a budget deficit level. It was observed that business cycle had crucial importance.

Summing up the discussion on the impact of monetary and fiscal policies restrictiveness/ expansiveness on the economy it must be added that a policy mix has a particular sense in the extraordinary conditions such as the financial crisis. Fiscal and monetary policies have influence on macroeconomic stability (Haberler 1976; Stiglitz 2007; Daianu 2019; Dallago 2019). The lack of an appropriate policy mix has not been found beneficial for economies. That is why this issue is so essential and should not be marginalized by the authorities (Stawska 2017). Additionally, within this debate and following authors like Czyżewski - Kułyk (2010) or Chiritescu Andrasiu (2010), the coordination mix must be analysed, especially for the European economic integration project. If there is nowadays a certain convergence of the mainstream authors with Haberler (1976) or with Stiglitz (2007) when these authors recognise fiscal and monetary policies are not innocuous and these policies do impact the economies, we cannot argue that there is a convergence whether the European policy has majorly been driven by the expansionary or restrictive policies along the last decades.

Author like Sarmento (2018) has argued that the European integration project has been, since its origin, a 'pro-keynesian' project, born in the peak of post-World War II Keynesianism's reputation. So, they claim the expansionary policies have dominated the Economic orientation, especially in EZ. By a reverse perspective, the studies from Driffil (2016) claim that monetarism has dominated the European integration project especially in the last decades. Authors like Binatli - Sohrabji (2019) reinforced the argument by making in evidence that the European common policies have been dominated by the pressure issued by the European Central Bank (ECB), and so, the restrictive policies have been the major characteristic of the European economic policy.

\section{DATA SOURCES AND THE EMPIRICAL EVIDENCE}

We used the data for the EZ from the Eurostat and IMF databases in the case of fiscal indicator as general government (GG) deficit (Eurostat) and as cyclically adjusted primary balance (IMF) excluding net interest payment (interest expenditure minus interest revenue). In the case of the monetary indicator as short-term and long-term interest rates data were from the Eurostat database (Short-term interest rates as money market interest rates - 3-month rate and long-term interest rates as the EMU convergence criterion series - annual data).

We started our analysis with the method used by Czyżewski - Kułyk (2010) as well as by Kopeć (2015). The application of the pendulum principle in economic policy stems from the need for economic policy to converge with the business cycle, mitigate its negative effects and, most importantly, maintain a decent level of economic growth (Basu - Taylor 1999). The use of the pendulum model for fiscal and monetary policy is intended to identify significant changes in the economic instability. These studies analysed variations of different tools of economic policy. In our suggestion nominal interest rates were used for discussing the drift of monetary policy (either considering the short-term or long-term interest rates). As an instrument of fiscal policy 
(conducted by the government), these studies recurred to the deficit of the General Government ${ }^{1}$ sector in relation to GDP (in the first version) and cyclically adjusted primary balance as \% of potential GDP (in the second version) were applied ( $d$ at Eq. (1)). The relative change in the interest rate, $r$ at Eq. (1) - (long-term or short-term interest rates) as well as the budget deficit and cyclically adjusted primary balance were then calculated based on the following formulas:

$$
d=\frac{d_{t}-d_{t-1}}{d_{t-1}} ; \quad r=\frac{r_{t}-r_{t-1}}{r_{t-1}}
$$

In order to determine options in monetary and fiscal policy, the indicators were standardized by presenting deviations from the average level for the examined period (X), as well as adopting a specific volatility index correcting the level of deviations expressed by standard deviation $(\mathrm{S}(\mathrm{x}))$. To this end, the following formulas were used (Czyżewski et al. 2006):

$$
d^{\prime}=\frac{\left(d_{t}-\bar{X}\right)}{S_{(x)}} ; \quad r^{\prime}=\frac{\left(r_{t}-\bar{X}\right)}{S_{(x)}}
$$

where $\bar{X}$ - arithmetic mean observed in the period; $S_{(x)}$ - standard deviation of the period.

For monetary policy, when the standardized long-term interest rate ratio is positive, then we can talk about the restrictive nature of monetary policy (as interest rates have risen) and when it is negative then monetary policy is classified as expansive because interest rates have decreased in relation to the previous period. For fiscal policy, when the standardised budget deficit ratio is positive then the government pursues an expansionary fiscal policy (because the deficit has increased) and when the ratio is negative - the government is considered as maintaining a restrictive fiscal policy (because the deficit has decreased compared to the previous period).

While setting a direction of economic policy $\left(P_{e}\right)$ the resultant of options used in monetary $\left(P_{m}\right)$ and fiscal policy $\left(P_{f}\right)$ was applied using the formula (Czyżewski et al. 2006):

$$
P_{e}=P_{m}-P_{f}
$$

When the difference value is negative, we have an expansive economic policy, meaning that the expansive effort overcomes the restrictive one. On the other hand, in the case of a positive difference, economic policy is restrictive.

The temporal window is relevant in the discussion too. Originally, it was also assumed that the business cycle lasts 3 years. The choice of the 3-year cycle in this article was based on Kitchin's short business cycles lasting 3-4 years or 2-4 years (and more accurate Kitchin's studies indicate on average 3.9 years of the business cycle) (Grinin et al. 2014; Piech 2001, 2002). Hence, due to the high frequency of changes on the financial markets in recent decades, it was decided to use the 3-year business cycle in this study. Additionally, options for fiscal, monetary and economic policy were also examined for 4-year and 5-year periods, due to alternative insights provided by Prusvic (2010) or Jones (2009).

\footnotetext{
${ }^{1}$ The general government sector is defined as consisting "of institutional units which are non-market producers whose output is intended for individual and collective consumption, and are financed by compulsory payments made by units belonging to other sectors, and institutional units principally engaged in the redistribution of national income and wealth" (ESA 2010).
} 


\subsection{Dominant trends in European fiscal policy}

Table 1 presents the results concerning the direction of fiscal policy in the EZ between 1999 and 2017. In the EA countries, fiscal policy is subject to the competence of national authorities; the effects of their actions affect other countries in the EZ and the EU having an impact on their macroeconomic situation (Leiner-Killinger - Nerlich 2019). The EZ countries, however, do not have complete freedom to conduct their national fiscal policies. It was already stipulated under

Table 1. Direction of fiscal policy in the Eurozone, 2000-2017

\begin{tabular}{|c|c|c|c|c|c|}
\hline Years & $\begin{array}{l}\text { GG budget } \\
\text { deficit in } \\
\% \text { GDP }\end{array}$ & $\begin{array}{c}\text { Annual relative } \\
\text { change in GG budget } \\
\text { deficit (Percentage } \\
\text { point) }\end{array}$ & $\begin{array}{l}\text { Standardized ratio } \\
\text { of change in deficit } \\
\text { (d' at Eq. (2)) }\end{array}$ & $\begin{array}{l}\text { Fiscal policy in } \\
\text { windows of } \\
\text { 3- years } \\
\text { (Percentage } \\
\text { point) }\end{array}$ & $\begin{array}{l}\text { Restrictiveness/ } \\
\text { Expansiveness of } \\
\text { fiscal policy }\end{array}$ \\
\hline 1999 & -1.5 & - & - & & \\
\hline 2000 & -0.5 & -0.7 & -0.9 & \multirow[t]{3}{*}{0.7} & \multirow[t]{3}{*}{ Expansionary } \\
\hline 2001 & -2.0 & 3 & 2.8 & & \\
\hline 2002 & -2.7 & 0.4 & 0.1 & & \\
\hline 2003 & -3.2 & 0.2 & -0.04 & \multirow[t]{3}{*}{-0.2} & \multirow[t]{3}{*}{ Restrictive } \\
\hline 2004 & -3.0 & -0.1 & -0.3 & & \\
\hline 2005 & -2.6 & -0.1 & -0.4 & & \\
\hline 2006 & -1.5 & -0.4 & -0.7 & \multirow[t]{3}{*}{0.2} & \multirow[t]{3}{*}{ Expansionary } \\
\hline 2007 & -0.7 & -0.5 & -0.8 & & \\
\hline 2008 & -2.2 & 2.1 & 1.9 & & \\
\hline 2009 & -6.3 & 1.9 & 1.7 & \multirow[t]{3}{*}{0.3} & \multirow[t]{3}{*}{ Expansionary } \\
\hline 2010 & -6.2 & -0.02 & -0.2 & & \\
\hline 2011 & -4.2 & -0.3 & -0.6 & & \\
\hline 2012 & -3.7 & -0.1 & -0.3 & \multirow[t]{3}{*}{-0.4} & \multirow[t]{3}{*}{ Restrictive } \\
\hline 2013 & -3.0 & -0.2 & -0.4 & & \\
\hline 2014 & -2.5 & -0.2 & -0.4 & & \\
\hline 2015 & -2.0 & -0.2 & -0.4 & \multirow{3}{*}{-0.5} & \multirow[t]{3}{*}{ Restrictive } \\
\hline 2016 & -1.5 & -0.3 & -0.5 & & \\
\hline 2017 & -0.9 & -0.4 & -0.6 & & \\
\hline 2018 & $x$ & $x$ & $x$ & - & - \\
\hline
\end{tabular}

Note: Based on GG deficit in 3-year periods.

Source: Own elaboration based on the Eurostat database. 
the EU Treaty that there are restrictions imposed on the countries joining the EU concerning the conduct of fiscal policy in the form of fiscal rules so that they cannot exceed the maximum amount of public debt and budget deficit representing 60\% of GDP and 3\% of GDP, respectively. Further principles are included in the Stability and Growth Pact obligating the EZ countries to implement the appropriate budgetary targets in the form of balancing or achieving a surplus in the medium term (ECB Monthly Bulletin, March 2011: 77). At this point, we should also note that fiscal policy is very heterogeneous between the countries in the EZ. Due to the lack of fiscal adjustment in some highly-indebted member states, fiscal policies are insufficiently adjusted, resulting in a slightly expansionary and pro-cyclical fiscal stance (European Parliament Briefing 2016).

In the period between 2000 and 2002, the governments of the countries in the EZ conducted an expansionary fiscal policy with the GG deficit ratios not exceeding the reference value from Maastricht i.e., 3\% of GDP. This deficit started to grow slightly until 2003 when it reached 3.2\%, but in response to such a situation in the EZ, a restrictive fiscal policy (2003-2005) was applied afterwards. Due to the increasing GG deficit between 2006 and 2008, an expansionary fiscal policy was identified. The expansionary direction of fiscal policy was continued also in the period between 2009 and 2011; this was a period of significant increase in GG deficits in the EA, which in $2009-2010$ amounted to $6.3 \%$ and $6.2 \%$ of GDP, respectively.

There were many factors that contributed to this situation. First and foremost, it was the financial crisis (Carlberg 2012; Pop et al. 2011) and, consequently, the fiscal crisis that mainly comprised Greece, Italy, Spain, Ireland and Portugal. The continuous increase in expenditure in relation to budget revenues and the financing of current liabilities from the sale of sovereign bonds translated into a failure to meet the fiscal criteria included in the Treaty on the functioning of the EU (Armingeon - Baccaro 2012). The expansive fiscal policy in the EZ countries contributed to measures aimed at a more coordinated and reinforced fiscal policy. So, in 2010, the European Commission introduced changes in the Stability and Growth Pact aimed at tightening the budgetary discipline of the member countries.

In the context of the public finance crisis and introduced rules and regulations, in order to limit the GG deficit in the EZ, it was preferred to conduct a restrictive fiscal policy between 2012 and 2017. In 2017, the GG deficit was $0.9 \%$ of GDP which showed a significant improvement if compared to years like 2011-2014.

The differences in the fiscal policy option in the analysed period based on cyclically adjusted balance in comparison to the GG deficit policy. We noted differences in two periods, namely in the years 2003-2005 and 2015-2017. In the case of fiscal policy measured by a cyclically adjusted balance, the fiscal policy was expansionary in contrast to the restrictive policy measured by GG deficit in two distinguished periods (Tables 1 and 2). We noted that in 2003-2005 the governments mostly pursued an expansive fiscal policy (as a result of the actions of governments from the EZ) similar to that in 2015-2017. It may be related to the relatively stable economic situation before the crisis of 2008-2009 and improvement of the economic situation after the last financial crisis.

Observing the fiscal policy options based on the cyclically adjusted primary balance, in the analysed period divided into 4 -year and 5-year periods, we notice slight differences. ${ }^{3}$ However,

\footnotetext{
${ }^{3}$ Results available on request.
} 
Table 2. Direction of fiscal policy in the Eurozone between 2000 and 2018

\begin{tabular}{|c|c|c|c|c|c|}
\hline Years & $\begin{array}{c}\text { Cyclically } \\
\text { adjusted primary } \\
\text { balance as } \% \text { of } \\
\text { potential GDP }\end{array}$ & $\begin{array}{c}\text { Annual relative } \\
\text { change in primary } \\
\text { balance } \\
\text { (Percentage } \\
\text { point) }\end{array}$ & $\begin{array}{l}\text { Standardized } \\
\text { ratio of change } \\
\text { in Primary } \\
\text { balance (d' at } \\
\text { Eq. (2)) }\end{array}$ & $\begin{array}{l}\text { Fiscal policy in } \\
\text { specific 3-years } \\
\text { period } \\
\text { (Percentage } \\
\text { point) }\end{array}$ & $\begin{array}{l}\text { Restrictiveness/ } \\
\text { Expansiveness of } \\
\text { fiscal policy }\end{array}$ \\
\hline 1999 & 2.2 & - & - & & \\
\hline 2000 & 2.3 & -0.05 & 0.2 & \multirow[t]{3}{*}{0.2} & \multirow[t]{3}{*}{ Expansionary } \\
\hline 2001 & 0.6 & 0.7 & 0.3 & & \\
\hline 2002 & 0.1 & 0.8 & 0.3 & & \\
\hline 2003 & 0.05 & 0.6 & 0.3 & \multirow[t]{3}{*}{0.2} & \multirow[t]{3}{*}{ Expansionary } \\
\hline 2004 & -0.06 & 2.2 & 0.3 & & \\
\hline 2005 & 0.1 & -2.6 & 0.1 & & \\
\hline 2006 & 0.3 & -2.0 & 0.1 & \multirow[t]{3}{*}{0.2} & \multirow[t]{3}{*}{ Expansionary } \\
\hline 2007 & 0.3 & -0.1 & 0.2 & & \\
\hline 2008 & -0.9 & 3.7 & 0.4 & & \\
\hline 2009 & -2.3 & 1.6 & 0.3 & \multirow[t]{3}{*}{0.2} & \multirow[t]{3}{*}{ Expansionary } \\
\hline 2010 & -2.7 & 0.1 & 0.2 & & \\
\hline 2011 & -1.3 & -0.5 & 0.2 & & \\
\hline 2012 & -0.01 & -1.0 & 0.2 & \multirow[t]{3}{*}{-1.3} & \multirow[t]{3}{*}{ Restrictive } \\
\hline 2013 & 1.0 & -108.3 & -4.2 & & \\
\hline 2014 & 1.0 & -0.01 & 0.2 & & \\
\hline 2015 & 1.0 & -0.02 & 0.2 & \multirow[t]{3}{*}{0.2} & \multirow[t]{3}{*}{ Expansionary } \\
\hline 2016 & 1.0 & -0.01 & 0.2 & & \\
\hline 2017 & 0.9 & -0.08 & 0.2 & & \\
\hline 2018 & 0.9 & -0.01 & 0.2 & - & - \\
\hline
\end{tabular}

Note: Based on cyclically adjusted primary balance in 3-year periods.

Source: Own elaboration based on the IMF database.

we also found an evidence favouring expansionary policies dominating along the observed period with the exception of the years 2010-2014 (dominated by a restrictive direction). By so far, we can argue these evidences have favoured Sarmento (2018). ${ }^{2}$

\footnotetext{
${ }^{2}$ With regard to the budget deficit, in the event of a budget surplus, the sign should be changed to the opposite one, so that the negative value means a reduction of the deficit or an increase in the budget surplus, and the positive represents the opposite phenomena.
} 


\subsection{Robustness checks - structural breaks and Markov-switching regimes in the series}

For testing the robustness of these findings, we recurred to two econometric techniques found useful for identifying structural breaks and regimes' changes in time series. Therefore, we used the technique for identifying multiple time breaks, and afterwards, we recurred to the identified "Markov-Switching models".

As Mourao (2018) refers "The history of the analysis of structural breaks in time series is well documented in works like Aue and Horvath (2013) or Lu and Ito (2008). From the first generations, focused on testing the statistical significance of structural breaks identified for precise moments (like the Chow test), we now have tests for unknown dates. Within these modern tests, we find the tests for multiple time breaks, like Clemente et al. (1998), whose critical values were previously suggested by Perron and Vogelsang (1992).”

The test of Clemente et al. (1998) let us analyse the nature of the break, differentiating between sudden breaks in the series ('additive outliers') or smooth changes ('innovational outliers'). Mourao Martinho (2016) referred that tests like that of Clemente et al. (1998) have additional convenience properties because they do not have so many restrictions on the stationarity of the series as tests like Bai - Perron (2003) impose, for instances, that the series must be I(0); i.e., stationary at the levels.

Using the forms of Baum (2015), we made $b_{t}$ referring to our series of the cyclically adjusted primary balance for each year (t) between 1999 and 2015. To test the presence of multiple additive outliers, we estimated the following system of Eq. (4):

$$
\begin{aligned}
& b_{t}=\alpha+\delta_{1} D U_{1 t}+\delta_{2} D U_{2 t}+e_{t} \\
& e_{t}=\sum_{i=1}^{k} w_{1 i} D T_{b 1, t-i}+\sum_{i=1}^{k} w_{2 i} D T_{b 2, t-i}+\rho e_{t-i}+\sum_{i=1}^{k} \theta_{i} \Delta e_{t-i}+z_{t}
\end{aligned}
$$

$\mathrm{DU}_{1 \mathrm{t}}=1$ for the year $\mathrm{t}$ after the first break time and zero, otherwise. Equivalently, $\mathrm{DU}_{2 \mathrm{t}}$ is equal to 1 for the time observation $t$ after the second break time and zero, otherwise. $T_{b 1}$ and $T_{b 2}$ identify the break points to be analysed by grid search (i.e., by identifying the minimal $t$-ratio for the hypothesis $\rho=1$ ). Following Baum (2015), we used $\mathrm{DT}_{\mathrm{bm}, \mathrm{t}}=1$ for $\mathrm{t}=\mathrm{T}_{\mathrm{bm}+1}$ and 0 for $\mathrm{m}=1,2$.

To test $\rho=1$ with the presence of innovational outliers, we analyzed the model provided by Eq. (5) (Baum 2015):

$$
b_{t}=\alpha+\delta_{1} D U_{1 t}+\delta_{2} D U_{2 t}+w_{1} D T_{b 1, t}+w_{2} D T_{b 2, t}+\alpha b_{t-i}+\sum_{i=1}^{k} \theta_{i} \Delta b_{t-i}+z_{t}
$$

Table 3's columns 1 and 2 show the results from the tests of Clemente et al. (1998) on the series of standardized ratio of change in primary balance (1999-2018) (Figs 1 and 2).

Table 3 suggests that the series composed by the Standardized Rate of Change of European Public Budgets has two breakpoints. The first occurs between 2010 (if assuming additive outliers) and 2011 (if assuming innovational outliers). The second breakpoint occurs between the years of 2013 (if assuming innovational outliers) and 2015 (if assuming additive outliers).

The years of the first identified period (2010-2011) are associated to important changes in the public finances in Europe. The rising unemployment rates across the European economies, the pressure from debt levels, the low European capacity for saving (Woroniecka-Leciejewicz, 2011) and the decrease of growth rates (or the accentuation of negative growth rates) generated significant challenges across Europe. As Table 3 shows, as a result, there was a significant decrease in primary balance which converged to our primary insight. 
Table 3. Clemente et al. (1998) test of structural breaks and Markov-Switching modelling of the standardised ratio of change in primary balance (UE-1999-2018)

\begin{tabular}{|c|c|c|c|}
\hline \multirow[b]{2}{*}{ Year } & \multicolumn{2}{|c|}{ Structural breaks ( $P$-values) } & \multirow{2}{*}{$\begin{array}{l}\text { Most-probable state } \\
\text { Markov-Switching dynamic regression, } \\
\text { switching variances }\end{array}$} \\
\hline & Additive outlier & Innovational outlier & \\
\hline 1999 & a) & a) & Expansionary \\
\hline 2000 & a) & a) & Expansionary \\
\hline 2001 & a) & a) & Expansionary \\
\hline 2002 & a) & a) & Expansionary \\
\hline 2003 & a) & a) & Expansionary \\
\hline 2004 & a) & a) & Expansionary \\
\hline 2005 & a) & a) & Expansionary \\
\hline 2006 & a) & a) & Expansionary \\
\hline 2007 & a) & a) & Expansionary \\
\hline 2008 & a) & a) & Expansionary \\
\hline 2009 & a) & a) & Expansionary \\
\hline 2010 & 0.023 & a) & Expansionary \\
\hline 2011 & a) & 0.000 & Expansionary \\
\hline 2012 & a) & a) & Restrictive \\
\hline 2013 & 0.040 & a) & Restrictive \\
\hline 2014 & a) & a) & Restrictive \\
\hline 2015 & a) & 0.536 a) & Expansionary \\
\hline 2016 & a) & a) & Expansionary \\
\hline 2017 & a) & a) & Expansionary \\
\hline
\end{tabular}

Note: a) Significance level higher than 0.100 .

The second identified period (2013-2015) also had important changes in the regulations of the European public finances. Overall, there have been increases of primary balances across most of the European economies (Woroniecka-Leciejewicz 2015). After economies like Spain and Portugal, other countries exhibited improvements in their primary balances.

However, following an established tradition in time series analysis (Hamilton 1994), we also recurred to the Markov-Switching models. These models have been found properly useful for identifying different states (also named 'regimes') in the observed time series. Following the most common notation, according to the Markov-Switching models, we started our discussion by considering a time series yt (observed from period $t=1, \ldots, \mathrm{T}$ ) modelled by a $\mathrm{K}$ number of states. Let us assume two states $(K=2)$. Therefore, yt can be differently modelled for State 1 or for State 2. 


\section{Clemente-Montanes-Reyes double IO test for unit root}
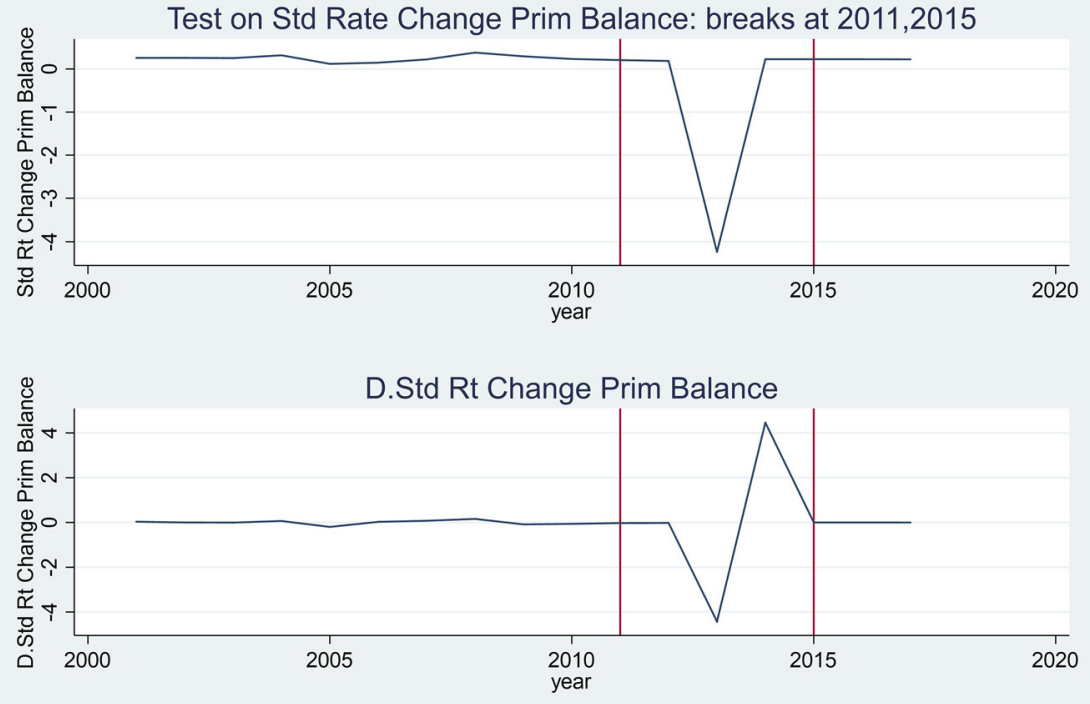

Fig. 1. Innovational outliers test for unit root (Series: Standardized ratio of change in public primary balance)

For State 1, yt is modelled as Eq. (6),

$$
\text { State } 1: y t=\mu 1+\varepsilon t
$$

For State 2, yt is modelled as Eq. (7) .

$$
\text { State 2: yt }=\mu 2+\varepsilon t
$$

In Eqs. (6) and (7), $\mu 1$ and $\mu 2$ are the intercept terms in state 1 and state 2, respectively. $\varepsilon$ t is assumed to follow standard assumptions: a white noise error with variance $\sigma 2$. The two states model differs in the intercept terms $(\mu 1$ and $\mu 2)$.

In a more general terminology, we can model Eqs. (6) and (7) as the Markov-switching regression model that will let the parameters to vary over the unobserved states:

$$
\mathrm{yt}=\mu \mathrm{st}+\varepsilon \mathrm{t}
$$

where $\mu$ st is the parameter of interest; $\mu$ st $=\mu 1$ when the observed state is of type $1(\mathrm{st}=1)$, and $\mu$ st $=\mu 2$ when the state is of type $2($ st $=2)$.

For estimating st, the conventional procedure was based on transition probabilities, which for $K=2$ were estimated in a matrix like the following:

$$
\left[\begin{array}{ll}
p 11 & p 21 \\
p 12 & p 22
\end{array}\right] \quad(\text { Matrix 1) }
$$

p11 denotes the probability of the series yt staying in state 1 in the next period given that yt is in state 1 in the current period. p12 relates to the probability of moving to state 2 after a 
Clemente-Montanes-Reyes double AO test for unit root
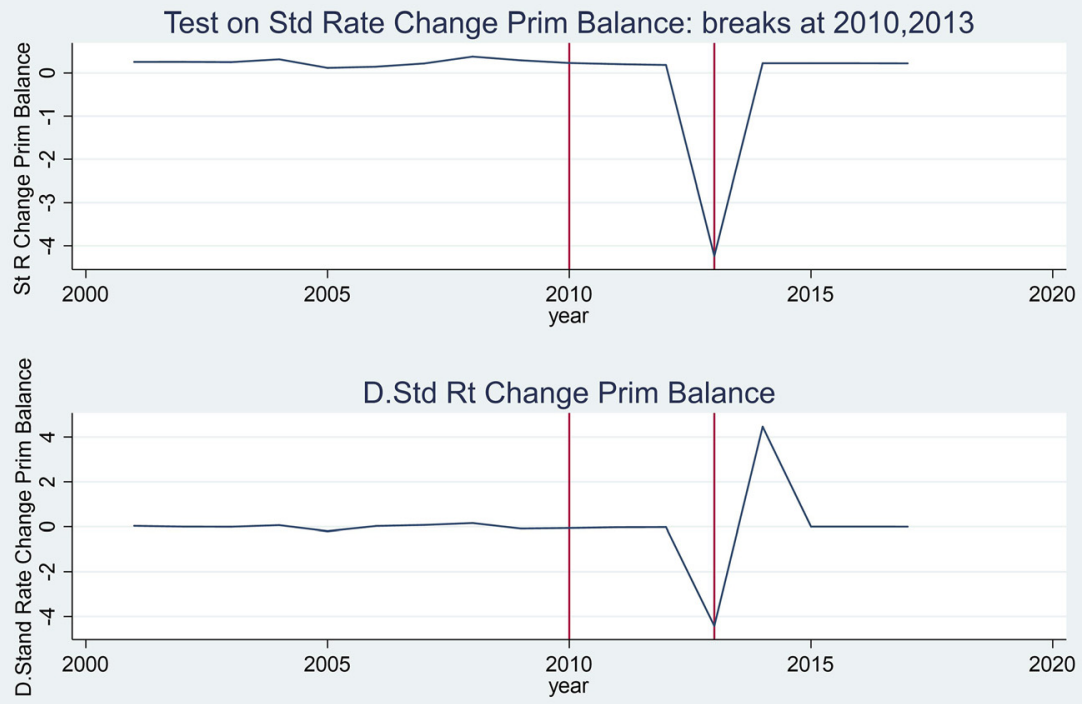

Note: At the vertical axes, the units are percent points (first panel) and difference to previous year in percent points (second panel); at the horizontal axes, the units refer to the observed year.

Fig. 2. Additive outliers test for unit root (Series: Standardized ratio of change in public primary balance)

period characterized by being in state 1. Conversely, p21 exhibits the estimated probability of transiting to state 1 after a period in state 2. p22 denotes the probability of staying in state 2 . More persistent processes are characterized by estimated probabilities being close to 1 .

Markov-Switching Dynamic Regressions (MSDR) are common estimation methods for testing the statistical significance of the different states, of the state-dependent means, or the error variance. Different specifications of MSDR allow to test the statistical significance of switching intercepts and coefficients, exogenous variables, and switching variances.

For measuring gradual adjustment after the process changes state, the Markov-Switching autorregresive (AR) models may also be estimated and analysed, without losing the possibility of extending the analysis to switching intercepts, coefficients, exogenous variables, and switching variances.

For discussing the preference for certain specifications, like the number of states among other features of the models' specification, criteria like AIC, BIC or SBIC were followed.

The third column of Table 3 identifies the most-probable State considering the MarkovSwitching Regressions for our focused series of Standardized Ratio of Change in Primary Balance. We estimated the following models:

-MS Dynamic Regression

-MSDR switching coefficients 
-MSDR switching variances

$-\mathrm{MS}$ AR

We will skip the full details of these specifications (available under request). For comparison purposes, the related SBIC values are:

-MS Dynamic Regression (SBIC $=-1.722$ )

- MSDR switching coefficients (SBIC $=-1.691)$

-MSDR switching variances $(\mathrm{SBIC}=-1.8538)$

$-\mathrm{MS}$ AR $(\mathrm{SBIC}=-1.442)$

Therefore, we preferred to model the series of Standardized Ratio of Change in Primary Balance as a MSDR with switching variances. Following this modelling, for each year we got estimates of the filtered transition probabilities which led us to identify the most-probable State for each year.

According to our estimates, State 1 is the expansionary state and has a mean standardized ratio of change of the deficit of $5.68 \%$. State 2 is the restrictive state and has a mean standardized ratio of change of $0 \%$. p11 is the estimated probability of staying in state 1 in the next period given that the process is in state 1 in the current period. We got an estimate of 0.94 for p1 1 which implies that state 1 is highly persistent. Similarly, p21 is the probability of transitioning to state 1 from state 2 . The estimated probability of staying in state 2 was estimated to be 0.01 , which implies that state 2 is highly temporary favouring the claims of Fracasso - Bonatti (2017) who suggested that the trend for the fiscal expansionary policies in the European space is a dominant one. As our preferred model was a MSDR switching variance, we also got estimated coefficients for each state's variance (sigma). State 1's sigma was estimated to be 0.057 (the standard error was estimated to be 0.009) which suggests a higher variability of the observed series in the expansionary state than in the restrictive one (State 2's sigma was estimated to be $4 \mathrm{e}-15$, without statistical significance).

Therefore, values in Table 3 show convergence with our previous interpretations from Tables 1 and 2 - there was a dominant trend of expansionary fiscal policies in the period between 1999 and 2017, with the exception of the sub-period between 2012 and 2015 (dominated by restrictive fiscal policies).

\subsection{Dominant trends in European monetary policy}

The ECB is responsible for conducting monetary policy in the EZ and affects inflation in the member countries. The ECB pursues its basic goal of maintaining a stable price level while subordinating the main directions of monetary policy, such as money supply, interest rate or exchange rate. The basic goal of the ECB is defined in Article 127 (1) and Article 282 (2) of the Treaty: » The main objective of the European System of Central Banks (...) is to maintain price stability«. The ECB may also take measures supporting the economic policies of the EZ countries only if it does not disturb the ECB's basic objective, i.e., price stability (following the consolidated version of the Treaty on European Union and the Treaty on the Functioning of the European Union, 2012).

Table 4 presents the results concerning the direction of the monetary policy in the EZ between 1999 and 2017, and following the descriptive methodology of Czyżewski - Kulyk (2010). 
Table 4. Direction of monetary policy in Eurozone between 2000 and 2017 based on long-term interest rate in 3-year periods

\begin{tabular}{|c|c|c|c|c|c|}
\hline Years & $\begin{array}{l}\text { Nominal long- } \\
\text { term interest } \\
\text { rate (\%) }\end{array}$ & $\begin{array}{l}\text { Annual relative } \\
\text { change in long- } \\
\text { term interest rate }\end{array}$ & $\begin{array}{c}\text { Standardized ratio } \\
\text { of change in } \\
\text { interest rate ( } r^{\prime} \text { at } \\
\text { Eq. (2)) }\end{array}$ & $\begin{array}{c}\text { Monetary } \\
\text { policy in } \\
\text { specific years }\end{array}$ & $\begin{array}{l}\text { Restrictiveness/ } \\
\text { Expansiveness of } \\
\text { monetary policy }\end{array}$ \\
\hline 1999 & 4.6 & - & - & & \\
\hline 2000 & 5.4 & 0.2 & 1.3 & \multirow[t]{3}{*}{0.5} & \multirow[t]{3}{*}{ Restrictive } \\
\hline 2001 & 5.0 & -0.1 & -0.1 & & \\
\hline 2002 & 4.9 & -0.02 & 0.2 & & \\
\hline 2003 & 4.1 & -0.2 & -0.5 & \multirow[t]{3}{*}{-0.3} & \multirow[t]{3}{*}{ Expansionary } \\
\hline 2004 & 4.1 & -0.01 & 0.3 & & \\
\hline 2005 & 3.4 & -0.2 & -0.6 & & \\
\hline 2006 & 3.8 & 0.1 & 1.0 & \multirow[t]{3}{*}{0.8} & \multirow[t]{3}{*}{ Restrictive } \\
\hline 2007 & 4.3 & 0.1 & 1.0 & & \\
\hline 2008 & 4.3 & -0.004 & 0.3 & & \\
\hline 2009 & 3.8 & -0.1 & -0.3 & \multirow[t]{3}{*}{0.4} & \multirow[t]{3}{*}{ Restrictive } \\
\hline 2010 & 3.6 & -0.1 & 0.03 & & \\
\hline 2011 & 4.4 & 0.2 & 1.5 & & \\
\hline 2012 & 3.9 & -0.1 & -0.3 & \multirow[t]{3}{*}{-0.9} & \multirow[t]{3}{*}{ Expansionary } \\
\hline 2013 & 3.0 & -0.2 & -0.9 & & \\
\hline 2014 & 2.0 & -0.3 & -1.4 & & \\
\hline 2015 & 1.2 & -0.4 & -1.9 & \multirow[t]{3}{*}{-0.4} & \multirow[t]{3}{*}{ Expansionary } \\
\hline 2016 & 0.9 & -0.3 & -1.2 & & \\
\hline 2017 & 1.1 & 0.3 & 1.8 & & \\
\hline
\end{tabular}

Source: Own elaboration based on the Eurostat database.

In the years of 2000-2002, the ECB conducted a restrictive monetary policy which could have been driven by the dynamic economic growth in 2000 (3.4\%), average inflation (2.4\%) exceeding the inflation target (2\% and below) and the growth rate of $\mathrm{M} 3(5.5 \%)$ remained above the reference value $(4.5 \%)$ throughout the year 2000. In 2000, the ECB raised the main interest rate from the level of $3 \%$ to $4.75 \%$. In 2001, as a result of the economic slowdown (real GDP growth in the EZ in 2001 amounted to $1.4 \%$ and in 2002 to $0.8 \%$ ), uncertainty in financial markets and falling HICP inflation (2.4\% in 2001 and 2.2\% in 2002), the ECB lowered its main refinancing operations rate from $4.75 \%$ at the beginning of 2001 to $2.75 \%$ at the end of 2002 (Annual Reports ECB 2001, 2002 and 2003). That is why the subsequent years, i.e., 2003-2005, 
were the period of expansive monetary policy in relation to the monetary policy in the earlier 3year period. Main refinancing operation rates in the EZ were reduced from $2.75 \%$ at the beginning of 2003 to $2.00 \%$ at the end of 2003 . The long-term interest rates were also falling along with the decrease in basic interest rates. At the beginning of 2004 the HICP inflation rate fell to the level below $2 \%$. The annual growth rate of M3 was steadily decreasing since the summer of 2003, falling to $5.3 \%$ - but in the second half of 2004 it reached the level of $6.4 \%$, which was largely stimulated by low interest rates. Real GDP in 2003-2005 remained at a relatively low level in 2003 (0.7\%), in 2004 (1.8\%) and in 2005 (1.4\%) (Annual Reports ECB 2004, 2005 and 2006).

In the periods between 2006-2008 and 2009-2011, the ECB's monetary policy measured by the nominal long-term interest rate was identified as restrictive. The real GDP growth rate increased to $2.8 \%$ in 2006 . However, already in 2008, there was a deterioration of the economic situation, especially after the tensions in the financial markets upon the collapse of Lehman Brothers. The average annual inflation increased from $2.2 \%$ in 2006 to $3.3 \%$ in 2008 . Main refinancing operation rate in 2006 increased to $3.5 \%$ and in 2007 up to $4 \%$. Annual long-term interest rate in the EZ in 2008 remained at $4.308 \%$. Despite the decline in the key interest rates in the EZ in 2009-2011, the long-term interest rate fluctuated from $3.8 \%$ in 2009 up to $4.4 \%$ in 2011, which, as a result, determined the restrictive nature of the monetary policy. From 2012 to 2017 we can talk about a trend of expansionary nature of the monetary policy. The long-term interest rate fell from $3.9 \%$ in 2012 up to $1.1 \%$ in 2017 . Main refinancing operation rates dropped from 1\% in 2012 up to $0 \%$ in 2016 and this level was maintained unchanged in 2017 (Table 4)

Now, we are going to comment on the perceived differences in monetary policy options based on the short-term interest rate. For short-term interest rate there was an expansionary monetary policy in 2000-2002 and 2009-2011, which could have been affected by a gradual reduction of interest rates during the periods of economic slowdown. In turn, in the years of 2015-2017, monetary policy became more restrictive as compared to the previous 3-year period (Table 5).

If we prefer to run the previous analyses but changing to windows of 4- and 5-years periods, we got additional insights. ${ }^{4}$ It is interesting that the directions of monetary policy in the EZ between 2000 and 2018 based on short-term interest rate in 4-year and 5-year periods are the same, either both expansive or both restrictive. Moreover, they almost coincided with the direction of monetary policy in 3-year periods, calculated on the basis of short-term interest rates.

Now, we move to a robustness check of our previous insight into the monetary policy between 1999 and 2017. As done in Table 3, in Table 6 we studied the structural breaks and the various regimes, but now in the series of standard ratio of change in European short-term interest rate.

Table 6 suggests that the series composed by the Standardized Rate of Change of European short-term interest rate has two breakpoints. Given the Additive Outliers' option (AO) were not characterized by statistically significant values, we only concentrated on the breaks identified by Innovational Outliers (IO). The first occurred in 2007 and the second in 2014.

\footnotetext{
${ }^{4}$ Results available on request.
} 
Table 5. Direction of monetary policy in the Eurozone between 2000 and 2018 based on short-term interest rate in 3-year periods

\begin{tabular}{|c|c|c|c|c|c|}
\hline Years & $\begin{array}{c}\text { Short-term } \\
\text { interest rate - } 3 \\
\text { M-money market } \\
\text { interest rates - } \\
\text { annual data }\end{array}$ & $\begin{array}{l}\text { Annual relative } \\
\text { change in long- } \\
\text { term interest rate }\end{array}$ & $\begin{array}{c}\text { Standardized } \\
\text { ratio of change in } \\
\text { interest rate }\left(r^{\prime} \text { at }\right. \\
\text { Eq. (2)) }\end{array}$ & $\begin{array}{l}\text { Monetary } \\
\text { policy in } \\
\text { specific 3- } \\
\text { years }\end{array}$ & $\begin{array}{l}\text { Restrictiveness/ } \\
\text { Expansiveness of } \\
\text { monetary policy }\end{array}$ \\
\hline 1999 & 3.0 & - & - & & \\
\hline 2000 & 4.4 & 0.5 & -0.02 & \multirow[t]{3}{*}{-0.2} & \multirow[t]{3}{*}{ Expansionary } \\
\hline 2001 & 4.3 & -0.03 & -0.2 & & \\
\hline 2002 & 3.3 & -0.2 & -0.3 & & \\
\hline 2003 & 2.3 & -0.3 & -0.3 & \multirow[t]{3}{*}{-0.2} & \multirow[t]{3}{*}{ Expansionary } \\
\hline 2004 & 2.1 & -0.1 & -0.2 & & \\
\hline 2005 & 2.2 & 0.03 & -0.2 & & \\
\hline 2006 & 3.1 & 0.4 & -0.05 & \multirow[t]{3}{*}{-0.1} & \multirow[t]{3}{*}{ Expansionary } \\
\hline 2007 & 4.3 & 0.4 & -0.1 & & \\
\hline 2008 & 4.6 & 0.1 & -0.2 & & \\
\hline 2009 & 1.2 & -0.7 & -0.5 & \multirow[t]{3}{*}{-0.2} & \multirow[t]{3}{*}{ Expansionary } \\
\hline 2010 & 0.8 & -0.3 & -0.3 & & \\
\hline 2011 & 1.4 & 0.7 & 0.1 & & \\
\hline 2012 & 0.6 & -0.6 & -0.4 & \multirow[t]{3}{*}{-0.4} & \multirow[t]{3}{*}{ Expansionary } \\
\hline 2013 & 0.2 & -0.6 & -0.4 & & \\
\hline 2014 & 0.2 & -0.05 & -0.2 & & \\
\hline 2015 & -0.02 & -1.1 & -0.6 & \multirow[t]{3}{*}{1.2} & \multirow[t]{3}{*}{ Restrictive } \\
\hline 2016 & -0.3 & 12.0 & 4.2 & & \\
\hline 2017 & -0.3 & 0.3 & -0.1 & & \\
\hline 2018 & -0.3 & -0.03 & -0.2 & & \\
\hline
\end{tabular}

Source: Own elaboration based on the Eurostat database.

We also estimated MS models, now for the Standardized Ratio of change in short-term interest rates. The related SBIC values are:

-MS Dynamic Regression $(\mathrm{SBIC}=0.772)$

$-\mathrm{MSDR}$ switching coefficients $(\mathrm{SBIC}=1.0261)$

$-\mathrm{MSDR}$ switching variances $(\mathrm{SBIC}=0.882)$

$-\mathrm{MS}$ AR $(\mathrm{SBIC}=0.5624)$ 
Table 6. Clemente et al. (1998) test of structural breaks and Markov-Switching modelling of the standardized ratio of change in short-term interest rates (UE-1999-2017)

\begin{tabular}{|c|c|c|c|}
\hline \multirow[b]{2}{*}{ Year } & \multicolumn{2}{|c|}{ Structural breaks ( $P$-values) } & \multirow{2}{*}{$\begin{array}{l}\text { Most-probable state } \\
\text { Markov-Switching dynamic regression, } \\
\text { switching variances }\end{array}$} \\
\hline & Additive outlier & Innovational outlier & \\
\hline 1999 & a) & a) & Expansionary \\
\hline 2000 & a) & a) & Expansionary \\
\hline 2001 & a) & a) & Expansionary \\
\hline 2002 & a) & a) & Expansionary \\
\hline 2003 & a) & a) & Expansionary \\
\hline 2004 & a) & a) & Expansionary \\
\hline 2005 & a) & a) & Expansionary \\
\hline 2006 & a) & a) & Expansionary \\
\hline 2007 & a) & 0.075 & Expansionary \\
\hline 2008 & a) & a) & Expansionary \\
\hline 2009 & a) & a) & Expansionary \\
\hline 2010 & a) & a) & Expansionary \\
\hline 2011 & a) 0.774 & a) & Expansionary \\
\hline 2012 & a) & a) & Restrictive \\
\hline 2013 & a) 0.269 & a) & Restrictive \\
\hline 2014 & a) & 0.001 & Restrictive \\
\hline 2015 & a) & a) & Restrictive \\
\hline 2016 & a) & a) & Expansionary \\
\hline 2017 & a) & a) & Expansionary \\
\hline
\end{tabular}

Note: a) Significance level higher than 0.100 .

Therefore, we preferred to model the series of Standardized Ratio of Change in European short-term interest rates as a MS-AR. Following this modelling, for each year we got again estimates of the filtered transition probabilities which led us to identify the most-probable State for each year.

The years of the second identified period (2014-2015) were associated to important changes in the monetary policy in Europe. This period accentuated rising values in the yearly relative change of the short-term interest rates. As Table 6 shows, this generated a distinct regime of the restrictive monetary policies.

The first identified period by the structural breaks' methodology (2007) also had important changes in the European monetary policy. Although the methodology proposed by Clemente 
et al. (1998) identified 2007 as a structural break, this year has not been validated by the MSAR as a start of a different regime. This is due to the preferred specification (MSAR) among the tested specifications which favoured the idea that the series composed by the standardized ratio of change in short-term interest rates is better modelled by a MSAR, characterized by the persistent regimes. Overall, these insights also converged with those from Tables 4 and 5.

Finally, we observed the dominant direction for the chosen indicator for the overall indicator of European economic policy. Based on the standardized ratios of fiscal and monetary policy, Table 7 presents the differences between these policies, and thereby, indicates an option of economic policy in the EZ. A negative value suggests an expansionary economic policy and a positive value suggests the presence of a restrictive one.

We noted that in 2000-2002 and in the years of 2003-2005, i.e., at the beginning of the analysed period, economic policy was expansionary, which may mean that in 2000-2002, the expansionary direction of monetary policy had a greater impact on economic policy, while 2003-2005 - expansionary direction of fiscal policy. In 2006-2011, a restrictive economic policy prevailed, the direction of which could be dominated by the restrictive fiscal policy (these years include the time to counteract the financial crisis and its consequences in the economies of the EZ) (Table 7).

In 2012-2014, the expansionary nature of the economic policy prevailed which could have been rooted in the expansionary monetary policy in the EA countries related to the quantitative easing programs (beginning in 2012) which brought interest rates to low levels. This period is characterized by low interest rates, unconventional methods of monetary policy (the ECB implemented negative interest rates and conducted major asset purchases in order to help stave off the effects of the global economic downturn), next deflation and low economic growth in the EA. In turn, the years of 2015-2017 are times of restrictive economic policy, which could largely influence the adoption of restrictive fiscal policy. Differences in economic policy options in the years of 2000-2017 based on short-term interest rates and cyclically adjusted primary balance compared to the long-term business rate policy option and GG deficit appeared in 2006-2008, 2009-2011 and 2012-2014 (Table 8).

Table 7. Direction of economic policy in the Eurozone between 2000 and 2017 in 3-years periods based on long-term interest rates and GG deficit

\begin{tabular}{|l|c|c|c|c|}
\hline Years & $\begin{array}{c}\text { Fiscal policy } \\
\text { (GG deficit) }\end{array}$ & $\begin{array}{c}\text { Monetary policy (long- } \\
\text { term interest rate) }\end{array}$ & $\begin{array}{c}\text { Economic } \\
\text { policy }\end{array}$ & $\begin{array}{c}\text { Expansiveness/ } \\
\text { Restrictiveness of } \\
\text { economic policy }\end{array}$ \\
\hline $2000-2002$ & 0.7 (expansionary) & 0.5 (Restrictive) & -0.2 & Expansionary \\
\hline $2003-2005$ & -0.2 (Restrictive) & -0.3 (expansionary) & -0.1 & Expansionary \\
\hline $2006-2008$ & 0.2 (expansionary) & 0.8 (Restrictive) & 0.6 & Restrictive \\
\hline $2009-2011$ & 0.3 (expansionary) & 0.4 (Restrictive) & 0.1 & Restrictive \\
\hline $2012-2014$ & -0.4 (Restrictive) & -0.9 (expansionary) & -0.5 & Expansionary \\
\hline $2015-2017$ & -0.5 (Restrictive) & -0.4 (expansionary) & 0.1 & Restrictive \\
\hline
\end{tabular}

Source: Own elaboration. 
Table 8. Direction of economic policy in the Eurozone between 2000 and 2017 in 3-years periods based on short-term interest rates and cyclically adjusted primary balance

\begin{tabular}{|l|c|c|c|c|}
\hline Years & $\begin{array}{c}\text { Fiscal policy (cyclically } \\
\text { adjusted balance) }\end{array}$ & $\begin{array}{c}\text { Monetary policy (short- } \\
\text { term interest rates) }\end{array}$ & $\begin{array}{c}\text { Economic } \\
\text { policy }\end{array}$ & $\begin{array}{c}\text { Expansiveness/ } \\
\text { Restrictiveness of } \\
\text { economic policy }\end{array}$ \\
\hline $2000-2002$ & 0.2 (expansionary) & -0.2 (expansionary) & -0.4 & Expansionary \\
\hline $2003-2005$ & 0.2 (expansionary) & -0.2 (expansionary) & -0.5 & Expansionary \\
\hline $2006-2008$ & 0.2 (expansionary) & -0.1 (expansionary) & -0.3 & Expansionary \\
\hline $2009-2011$ & 0.2 (expansionary) & -0.2 (expansionary) & -0.5 & Expansionary \\
\hline $2012-2014$ & -1.3 (Restrictive) & -0.4 (expansionary) & 0.9 & Restrictive \\
\hline $2015-2017$ & 0.2 (expansionary) & 1.2 (Restrictive) & 0.9 & Restrictive \\
\hline
\end{tabular}

Source: Own elaboration.

In 2006-2011, both monetary and fiscal policy were characterized by expansiveness, hence economic policy was also expansive (including the period of the recent economic crisis). In turn, in 2012-2014, the economic policy turned out to be restrictive, which could have resulted from the dominance of the restrictive fiscal policy in this period (Table 8).

Observing the indicator for economic policy options based on the short-term interest rate, in the analysed period divided into 4 -year and 5-year periods, ${ }^{5}$ we noticed slight differences mainly due to time shifts and dominant option of monetary or fiscal period. It must be also emphasized that in some periods the policies cancelled each other, which means that when one of them was of restrictive nature, the other one showed expansiveness.

At last, we ran a robustness check regarding our indicator of Economic Policy between 1999 and 2017. As previously done, we identified the structural breaks and various regimes, but now in the series of the differences between the standardized ratio of change in short-term interest rates and the standardized ratio of change in primary balance.

Table 9, Figs 3 and 4 suggest that the series composed by the differences between the Standardized Rate of Change of European short-term interest rate and the Standardized Rate of Change of European public balance had one statistically significant breakpoint (based on IO). This breakpoint occurred in 2011, already commented as one of the years with the most critical values of most of economic indicators.

We also estimated MS models, now for the Standardized Ratio of change in short-term interest rates. The related SBIC values are:

-MS Dynamic Regression $(\mathrm{SBIC}=1.023)$

- MSDR switching coefficients $($ SBIC $=1.0667)$

$-\mathrm{MSDR}$ switching variances and coefficients $(\mathrm{SBIC}=0.8741)$

-MS AR (SBIC = 0.9645)

\footnotetext{
${ }^{5}$ Results available on request.
} 
Table 9. Clemente et al. (1998) test of structural breaks and Markov-Switching modelling of the standardized ratio of change in short-term interest rates (UE-1999-2017)

\begin{tabular}{|c|c|c|c|}
\hline \multirow[b]{2}{*}{ Year } & \multicolumn{2}{|c|}{ Structural breaks ( $P$-values) } & \multirow{2}{*}{$\begin{array}{l}\text { Most-probable state } \\
\text { Markov-Switching dynamic regression, } \\
\text { switching variances }\end{array}$} \\
\hline & Additive Outlier & Innovational Outlier & \\
\hline 1999 & a) & a) & Expansionary \\
\hline 2000 & a) & a) & Expansionary \\
\hline 2001 & a) & a) & Expansionary \\
\hline 2002 & a) & a) & Expansionary \\
\hline 2003 & a) & a) & Expansionary \\
\hline 2004 & a) & a) & Expansionary \\
\hline 2005 & a) & a) & Expansionary \\
\hline 2006 & a) & a) 0.639 & Expansionary \\
\hline 2007 & a) & a) & Expansionary \\
\hline 2008 & a) 0.818 & a) & Expansionary \\
\hline 2009 & a) & a) & Expansionary \\
\hline 2010 & a) 0.257 & a) & Expansionary \\
\hline 2011 & a) & a) 0.001 & Restrictive \\
\hline 2012 & a) & a) & Restrictive \\
\hline 2013 & a) & a) & Restrictive \\
\hline 2014 & a) & a) & Restrictive \\
\hline 2015 & a) & a) & Restrictive \\
\hline 2016 & a) & a) & Restrictive \\
\hline 2017 & a) & a) & Restrictive \\
\hline
\end{tabular}

Note: a) Significance level higher than 0.100 .

Therefore, we preferred to model the series of the differences between Standardized Ratio of Change in European short-term interest rates and Standardized Ratio of Change in European primary balance as a MSDR with switching variances and coefficients. Following this modelling, for each year we got estimates of the filtered transition probabilities which led us to identify the most-probable State for each year (third column in Table 9).

The years after 2014 are associated to a different regime in the observed series. As Table 9 shows, this period is associated to restrictive combined policies.

Once again, these insights also converge with those from Tables 7 and 8 . The evidence in Table 9 is promising to be discussed because we checked there a clear change of an expansionary regime in European economic policy to a restrictive one, especially after 2012, although the 
Clemente-Montanes-Reyes double AO test for unit root
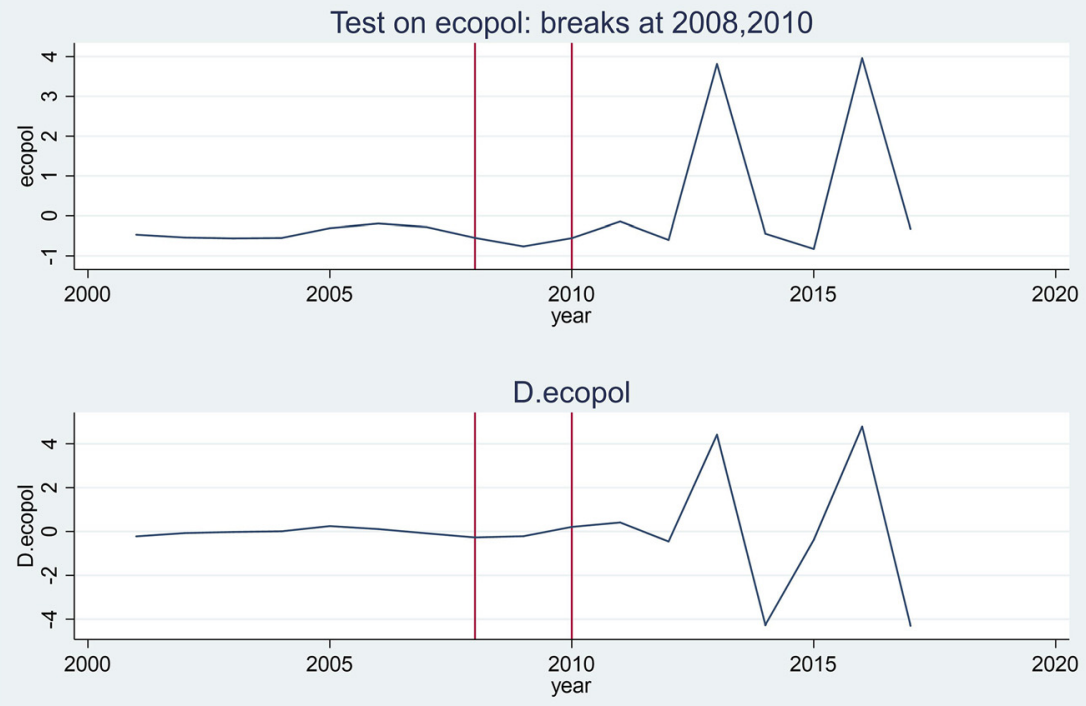

Fig. 3. Test for structural breaks (European economic policy, additive outliers)

Clemente-Montanes-Reyes double IO test for unit root Test on ecopol: breaks at 2006,2011
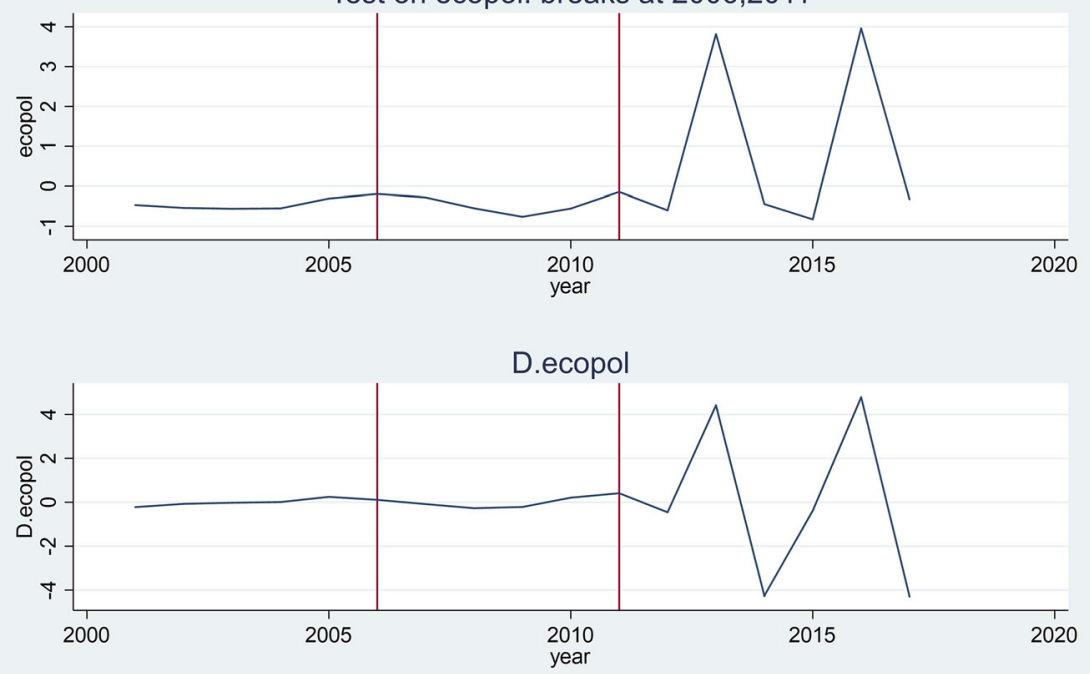

Fig. 4. Test for structural breaks (European economic policy, additive outliers) 
differences found for the series associated to fiscal policy or to monetary policy. Therefore, although the dominance of expansionary policies found at the inception of the Euro project, the most recent signals coming from European economic policy suggest a drift toward a more restrictive direction, which converges with theses from Faini (2006), Stigliz (2016) or Lipovska (2018).

\section{CONCLUSION, POLICY IMPLICATIONS AND FURTHER CHALLENGES}

Studying fiscal and monetary outputs, we concluded that during the economic slowdown (20012002), the financial crisis (2008-2009) and during the crisis of public finances in the EZ (20102011) the expansionary fiscal policy and the restrictive monetary policy were alternatively applied. In turn, in the years of 2015-2017, the expansionary monetary policy and the restrictive fiscal policy were introduced. In the years of 2000-2011, there were expansionary monetary and fiscal policies. On the other hand, in the years of 2012-2017, the economic policy was restrictive. In the years of 2015-2017, the restrictive monetary policy prevailed in comparison to the expansive fiscal policy.

The above results and the analysis of dependencies in the EZ economy favour the evidence that economic authorities have sought to coordinate monetary and fiscal policy in order to stabilise the economy. For an enlightened answer to our major motivation, we can clearly state that if the Euro project was born involved by pro-Keynesian and expansionary policies (either monetary or fiscal ones), the most recent years were characterised by the restrictive economic policies, which shows different insights assumed by the European policymakers.

These conclusions led us to insert two major policy implications. As we observed, economic policies' main direction tends to last. Therefore, as we noticed a long period of expansionary policies at the Euro's inception, it is also expectable that we will observe a so long duration in the dominance of current restrictive policies, unless unprecedented events, economic shocks or crises occur. Additionally, there has a certain simultaneity of the direction of fiscal policies with the direction of monetary ones; therefore, we can claim there has been a certain convergence of policies in these two different dimensions of European economic life. However, it would be challenging to discuss and to analyse the probable consequences of different directions in these dimensions at the same period.

As there are numerous factors distorting the coordination of monetary and fiscal policy, and thereby, influencing the effectiveness of economic policy, we suggest to analyse them in details. These factors include, for instance, the diverse objectives and preferences of economic authorities, delays in implementation of fiscal and monetary policy as well as internal and external economic impulses such as financial crises. In addition, there is a complex system of economic and political integration in the EZ, including the asymmetry of budget cycles or political cycles and associated electoral opportunism, which can be taken into account for further studies on these topics.

\section{ACKNOWLEDGEMENT}

The study was financed from the funds of the National Science Centre Poland in the period between 2018 and 2021 under the title: "The coordination of the monetary and fiscal policies in the studies of the monetary-fiscal interactions based on the game theory - the case of the European Union countries". Contract number is UMO-2017/26/D/HS4/00954. This paper is also 
financed by National Funds of the FCT - Portuguese Foundation for Science and Technology within the project UIDB/03182/2020.

\section{REFERENCES}

Armingeon, K. - Baccaro, L. (2012): Political Economy of the Soverign Debt Crisis: The Limit of Internal Devaluation. Industrial Law Journal, 41(3): 254-275.

Aue, A. - Horvath, L. (2013): Structural Breaks in Time Series. Journal of Time Series Analysis, 34(1): 1-16. Badarau, C. - Levieuge, G. (2011): Which Policy-Mix to Mitigate the Effects of Financial Heterogeneity in a Monetary Union? LAREFI Working Paper, No. CR11-EFI/09, pp. 2-3.

Bai, J. - Perron, P. (2003): Critical Values for Multiple Structural Change Tests. Econometric Journal, 6(1): $72-78$.

Basu, S. - Taylor, A. (1999): Business Cycles in International Historical Perspective. Journal of Economic Perspectives, 13(2): 45-68.

Baum, C. (2015): Stata: The Language of Choice for Time-Series Analysis? Stata Journal, 3(1):1-31.

Bennett, H. - Loayza, N. (2000): Policy Biases when the Monetary and Fiscal Authorities Have Different Objectives. Central Bank of Chile Working Papers, No. 66: 1-46.

Binatli, A. O. - Sohrabji, N. (2019): Monetary Policy Transmission in the Euro Zone. Athens Journal of Business and Economics, 5(1): 79-95.

Blake, A. P. - Weale, M. (1998): Cost of Separating Budgetary Policy from Control of Inflation: A Neglected Aspect of Central Bank Independence. Oxford Economic Papers, No. 50, pp. 449-467.

Buti, M. (ed.) (2003): Monetary and Fiscal Policies in EMU: Interactions and Coordination. Cambridge: Cambridge University Press.

Cabral, R. - Garcia, D. R. (2015): Is Fiscal Policy Coordination Desirable for a Monetary Union? An Assessment from the Perspective of a Small Open Economy. UNAM, Investigación Económica, LXXIV(294): 3-72.

Canzoneri, M. B. - Cumby, R. E. - Diba, B. T. (2006): How Do Monetary and Fiscal Policy Interact in the European Monetary Union? NBER Working Paper, No. 11055.

Carlberg, M. (2012): Unemployment and Inflation in Economic Crisis. Springer.

Chadha, J. S. - Nolan, Ch. (2007): Optimal Simple Rules for the Conduct of Monetary and Fiscal Policy. Journal of Macroeconomics, 29(4): 665-689.

Chirtescu, D. D. - Andrasiu, A. (2010): Euro Zone and its Monetary Policy. Constantin Brancusi University, Faculty of Economics, Annals - Economy Series, 1(April): 49-52.

Clarida, R. - Galí, J. - Gertler, M. (2000): Monetary Policy Rules and Macroeconomic Stability: Evidence and Some Theory. Quarterly Journal of Economics, 115(1): 147-180.

Clemente, J. - Montañés, A. - Reyes, M. (1998): Testing for a Unit Root in Variables with a Double Change in the Mean. Economics Letters, 59(2):175-182.

Cui, W. (2016): Monetary-Fiscal Interactions with Endogenous Liquidity Frictions. European Economic Review, 87(August): 1-25.

Czyżewski, A. - Poczta, A. - Wawrzyniak, Ł. (2006): Interesy europejskiego rolnictwa w świetle globalnych uwarunkowań polityki gospodarczej (The Interests of European Agriculture in the Light Global Conditions of Economic Policy Making). Ekonomista, 3: 347-369. 
Czyżewski, A.- Kułyk, P. (2010): Relacje między otoczeniem makroekonomicznym a rolnictwem w krajach wysoko rozwiniętych w Polsce w latach 1991-2008 (Relations between the Macroeconomic Environment and Agriculture in Highly Developed Countries in Poland in 1991-2008). Ekonomista, 2: 189-212.

Daianu, D. (2019): Revisiting Euro Area Accession Terms: Fiscal Rectitude Is Not Sufficient! Acta Oeconomica, 69(S): 73-97.

Dallago, B. (2019): Comparative Economics, Globalization and the Eurozone in Quest for a New Eurozone Paradigm. Acta Oeconomica, 69(S): 99-119.

Demertzis, M. - Hallet, A. H. - Viegi, N. (2002): An Independent Central Bank Faced with Elected Governments. Research Memorandum, No. 686, De Nederlandsche Bank.

Dixit, A. - Lambertini, L. (2003): Interactions of Commitment and Discretion in Monetary and Fiscal Policies. The American Economic Review, 93(5): 1522-1542.

Driffill, J. (2016): Unconventional Monetary Policy in the Euro Zone. Open Economies Review, 27(2): 387404.

ECB (2011): Monthly Bulletin - March 2011, p.77; http://www.ecb.int/pub/pdf/other/ 10thanniversaryoftheecbmb200806pl.pdf.

European Parliament Briefing (2016): The Euro Area Fiscal Stance http://www.europarl.europa.eu/ RegData/etudes/BRIE/2016/587374/IPOL_BRI(2016)587374_EN.pdf.

Faini, R. (2006): Fiscal Policy and Interest Rates in Europe. Economic Policy, 21: 443-489. https://doi.org/ 10.2139/ssrn.2040815.

Fand, D. (1969): Keynesian Monetary Theories, Stabilization Policy and the Recent Inflation. Journal of Money, Credit and Banking, 1(3): 588-589.

Ferré, M. (2008): Fiscal Policy Coordination in the EMU. Journal of Policy Modelling, 30(2): 221-235.

Flanagan, K. - Uyarra, E. - Laranja, M. (2011): Reconceptualising the 'Policy Mix' for Innovation. www. imf.org.

Fracasso, A. - Bonatti, L. (2017): Addressing the Core-Periphery Imbalances in Europe: Resource Misallocation and Expansionary Fiscal Policies. EconPol Working Paper, No. 6, ifo Institute - Leibniz Institute for Economic Research at the University of Munich.

Grinin, L. E. - Devezas, T. C. - Korotayev, A. V. (2014): Kondratieff Waves. Juglar - Kuznets - Kondratieff. Volgograd: Uchitel Publishing House.

Haberler, G. (1976): Crescimento Econômico e Estabilidade (Uma Análise da Evolução e das Políticas Econômicas) (Economic Growth and Stability) (An Analysis of the Evolution of Economic Policies). Rio de Janeiro: Zahar.

Hamilton, J. D. (1994): Time Series Analysis. New Jersey: Princeton University Press.

Jacquet, P. - Pisani-Ferry, J. (2001): Economic Policy Co-Ordination in the Euro-Zone. What Has Been Achieved? What Should be Done? Sussex European Institute (SEI) Working Paper, No. 40.

Jones, E. (2009): European Fiscal Policy Coordination and the Persistent Myth of Stabilization. In: Talani,

L. (ed.): The Future of EMU. Basingstoke, Hampshire: Palgrave Macmillan, pp. 29-53.

Kopeć, B. (2015): Identyfikacja opcji polityki gospodarczej i ich związku z inflacją i bezrobociem (Identification of Economic Policy Options and their Relation to Inflation and Unemployment). Progress in Economic Sciences, 2: 28-34.

Kuttner, K. N. (2002): The Monetary - Fiscal Policy Mix: Perspectives from the U. S. Bank i Kredyt, 33(1112).

Leiner-Killinger, N. - Nerlich, C. (2019): Fiscal Rules in the Euro Area and Lessons from Other Monetary Unions. ECB Economic Bulletin, Issue 3. 
Lipovská, H. (2018): Joseph E. Stiglitz: Euro - How a Common Currency Threatens the Future of Europe. Central European Journal of Public Policy, 12(2): 1-4.

Lu, S. Q. - Ito, T. (2008): Structural Breaks and Time-Varying Parameter: A Survey with Application. Communications of the IBIMA, 2: 129-135.

Midthjell, N. L. (2011): Fiscal Policy and Financial Crises - What Are the Actual Effects of Fiscal Policy? Norges Bank, Economic Bulletin, 82: 24-38.

Mourao, P. (2018): Smoking Gentlemen - How Formula One Has Controlled CO2 Emissions. Sustainability, 10(6): 1841.

Mourao, P. - Martinho, V. (2016): Discussing Structural Breaks in the Portuguese Regulation on Forest Fires - An Economic Approach. Land Use Policy, 54: 460-478.

Nordhaus, W. (1994): Policy Games: Coordination and Independence in Monetary and Fiscal Policies. Brooking Paper on Economic Activity, No. 2.

Payer, Ch. (1974): A Armadilha da divida exterma: o Fundo Monetário Internacional e o desenvolvimento da dependencia (The Trap of External Debt - The IMF and the Development of the External Dependence). San Paulo: Moraes Editores.

Perron, P. - Vogelsang, T. (1992): Nonstationary and Level Shifts with an Application to Purchasing Power Parity. Journal of Business Economic \& Statistics, 10(3): 301-320.

Piech, K. (2001-2002): Rodzaje cykli gospodarczych (Types of Economic Cycles). Polityka gospodarcza, No. 5-6: 262-267.

Pisani-Ferry, J. (2012): Fiscal Discipline and Policy Coordination in the Eurozone: Assessment and Proposal. In: Paganetto, L. (ed.): The Political Economy of the European Constitution. Famham, UK: Ashgate Publishing, pp. 119-140.

Pop, N. - Lupu, I. - Milea, C. - Criste, A. - Iordache, F. - Alinca, A. G. (2011): The Euro Crisis or the Crisis of the Euro Zone. Financial Studies, 15(2): 148-169.

Prušvic, D. (2010): European Fiscal Policy Rules: First 15 Years. Politická ekonomie, (1): 51-69.

Samuelson, P. A. (1968): What Classical and Neoclassical Monetary Theory Really was. The Canadian Journal of Economics, 1(1): 1-15.

Sargent, T. S. - Wallace, N. (1981): Some Unpleasant Monetarist Arithmetic. Quarterly Review, 5(3): 1-19, Federal Reserve Bank of Minneapolis.

Sarmento, J. (2018): Reforming Europe and the Euro Zone. Financial and Monetary Policy Studies. In: National Accounts in the European Context. Springer, pp. 37-45.

Saulo, H. - Rego, L. C. - Divino, J. A. (2013): Fiscal and Monetary Policy Interactions: A Game Theory Approach. Annals of Operations Research, 206(1): 341-366.

Snowdon, B. - Vane, H. - Wynarczyk, P. (1996): Współczesne nurty teorii makroekonomii (Contemporary Trends in the Theory of Macroeconomics). Warsaw: PWN, pp. 105-106.

Stawska, J. (2017): The Phenomenon of Low Interest Rates in the Context of Monetary and Fiscal Interaction (Policy Mix). In: Proceedings of the 4th International Multidisciplinary Scientific Conference on Social Science and Arts. Vol. 4: Modern Science, Economics - Tourism. Sofia: STEF 92 Technology Ltd, pp. 777-784.

Stiglitz, J. E. (2007): Making Globalization Work. W. W. Norton \& Company, Inc.

Stiglitz, J. E. (2016): Euro - How a Common Currency Threatens the Future of Europe. W. W. Norton \& Company, Inc.

von Hagen, J. (2004): Fiscal Sustainability in EMU: From the Stability and Growth Pact to a Sustainability. Council for EMU. CESifo Working Paper. http://www.cesifo-group.de/portal/page?_pageid=36, 103017\&_dad=portal\&_schema=PORTAL\&item_link=del04-porogramme.htm. 
von Hagen, J. - Mundschenk, S. (2003): Fiscal and Monetary Policy Coordination in EMU. International Journal of Finance and Economics, 8(4): 279-295.

Woroniecka-Leciejewicz, I. (2011): Analiza Policy-mix z Uwzględnieniem Interakcji Decyzyjnych Między Bankiem Centralnym a rządem i ich Priorytetów (Policy Mix Analysis Taking into Account the Decision-Making Interactions Between the Central Bank and the Government and their Priorities). Zeszyty Naukowe Wydziału Informatycznych Technik Zarządzania Wyższej Szkoły Informatyki Stosowanej Zarzadzania. Współczesne Problemy Zarzadzania, 1: 39-62.

Woroniecka-Leciejewicz, I. (2015): Wpływ Instrumentów Policy-mix na Gospodarkę - Ujęcie Modelowe (The Influence of Policy-mix Instruments on the Economy - A Modeling Approach). Wspótczesne Problemy Zarządzania. Zeszyty Naukowe Wydziału Informatycznych Technik Zarządzania Wyższej Szkoły Informatyki Stosowanej i Zarzadzania, 1: 7-33. 